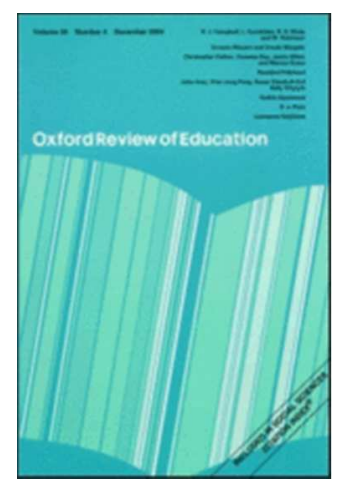

\title{
'Poetry is not a special club': how has an introduction to the secondary Discourse of Spoken Word made poetry a memorable learning experience for young people?
}

\begin{tabular}{|r|l|}
\hline Journal: & Oxford Review of Education \\
\hline Manuscript ID & CORE-2016-0099.R1 \\
\hline Manuscript Type: & Article \\
\hline Keywords: & poetry, Spoken Word, writing, listening, learning, performance \\
\hline
\end{tabular}

SCHOLARONE ${ }^{\text {m }}$

Manuscripts 


\section{'Poetry is not a special club': how has an introduction to the secondary Discourse of Spoken Word made poetry a memorable learning experience for young people?}

This paper explores the impact of a Spoken Word Education Programme (SWEP hereafter) on young people's engagement with poetry in a group of schools in London, UK. It does so with reference to the secondary Discourses (Gee, 2015, p. 165) of school-based learning and the Spoken Word community, an artistic 'community of practice' (Wenger, 1997, p. 1) into which they were being inducted. It focuses on what happened when secondary students, already enculturated into school Discourses about learning (in their English lessons especially), learned about new ways of being readers, writers, listeners and performers through the SWEP Discourse. The paper draws on qualitative data collected during the first three years of programme development to consider how an introduction to the social practices of this artistic community appeared to influence 11-18 year old students' attitudes to poetry study, discussion, writing and performance both in school and beyond the parameters of traditional secondary school learning.

\section{Discourses}

Gee identifies primary Discourses as 'ways of behaving, interacting, valuing, thinking, believing, speaking, and often reading and writing, that are accepted instantiations of particular identities... ways of being "people like us"' $(2015$, p. 3). Like most individuals, young people assume a range of socially situated identities that are borne out of their affiliations. Through these, they become 'apprenticed to' (p. 165) multiple secondary Discourses including those of school. Gee argues that school is a site where such discourses can 'operate to integrate, divide, and sort people and groups' (p. 4). A key element is the 'social practice' (Scribner \& Cole, 1981, p.236) of how language is used within the Discourse. The greater the distance that exists between one's primary and other, secondary, Discourses, the greater the challenge there will be to perform within a Discourse, to access its social practices, gain entry and become fluent in its literacy (Gee 2015). This challenge is particularly significant for young people especially those who live and learn in difficult circumstances and have previously lacked opportunities to become fluent performers in the secondary Discourse of school learning. The SWEP appeared to 
give young people access to Spoken Word practices and other ways of learning with literacy. It did not guarantee them membership of that community but provided an important bridge towards it.

\section{School learning Discourse}

Biesta suggests there are three key elements to 'Good Education' in policy terms: qualification, socialisation and subjectification (2010, pp. 19 - 21). A major thread within 'qualification' is how pupils' progress in England is mapped against national performance measures including examination results. Each school is held accountable for target setting and student progress thus creating a 'pressurecooker' environment (Perryman, Ball, Maguire \& Braun 2011, p.179) which is particularly felt by English and Mathematics teachers. Ball perceives this accountability as 'a powerful and insidious policy technology' (2012, p. 17). For Pring, school target culture leads to a 'depersonalisation' of learning (2012, p. 747), endangering the complex web of community relationships that are vital for a young person's growth (p.757).

Socialisation (Biesta, 2010, p. 19) is another element within this Discourse. School communities have explicitly stated expectations about how students should participate in school life within lessons and beyond timetabled hours. Clark (1998) identifies binaries of control and discipline as significant in this respect. Control of students is necessary if schools are to successfully 'deliver' curricula and raise achievement in examination results/national league table positions. Discipline ensures that students 'subscribe' (1998, p.265) and adhere to expectations and values about learning. The standards agenda requires schools to have appropriate policies for 'managing behaviour' (DfE, 2015, p. 3) and is one of the 'technologies through which a school maintains its view of order' (Maguire, Ball \& Braun, 2010, p.153).

Biesta's third category 'subjectification' (2010, p. 76) refers to how individuals' learning is supported. Support is underpinned by an imperative that all students 'make progress and fulfil their potential' (Ofsted, 2015, pt 14, 6). Examples of subjectification include intervention classes (during and after school hours) and other types of targeted support for students with identified special learning needs and/or in receipt of Pupil Premium funds ${ }^{1}$. Individual students who are considered unlikely to achieve 
their target grades are subject to substantial scrutiny. In many schools their names, photographs and targets are displayed in staffrooms as a reminder of teachers' responsibility to close the 'gap' (Sadler, 1989 , p. 119) between what students have learned and what they have achieved.

\section{English teaching and learning}

Subject English (in England) is currently framed by neo-liberal discourses regarding curriculum content and subject knowledge acquisition that can 'marginalise and obscure' (Anderson, 2015, p. 36) learning and learners. For example, during a typical secondary school English lesson in England, students (aged 11 -16) engage in highly structured activities often linked to very small sections of texts. During such activities, students' progress against predetermined, differentiated subject targets is frequently reviewed by their teacher. In addition, they might participate in scaffolded peer/self assessment processes through which additional targets are arrived at. Students might be required to use acronyms to structure their reading, talk and writing about texts and assessment dialogues. Such tightly framed processes can lead to production of 'schooled responses' (Misson and Morgan 2006, p. 107) showing limited development of ideas that do not neatly match previously established assessment criteria. Thus, learning can become focused primarily on acquisition of a package of factual knowledge (Hirsch 2012) and an English teacher's role could be perceived as a 'learning accountant' rather than a 'creative curriculum maker' (Author, 2016, p. 73 ). Knowledge is banked and revisited many times in order to fulfil exam requirements, rather than developed collaboratively, as Yandell (2011) describes, through use of pedagogic practices that draw on students' own cultural experiences.

\section{Poetry teaching and learning}

Poetry is one aspect of the English curriculum which is widely acknowledged to present specific pedagogic and learning challenges. Many teachers, working in different contexts, appear to lack confidence in the genre (Benton, 2000; Author \& Hughes, 2009). Some evidence suggests that poetry is the least well-taught part of English curricula internationally and that high stakes assessments have exacerbated this situation (Ofsted, 2007; Locke, 2009). The National Curriculum in England requires that students aged 11-14 years are taught to: read 'high-quality works from English literature'; recognise poetic conventions and understand their use; write poetry; improvise, rehearse and perform 
poetry 'in order to generate language and discuss language use and meaning' (DfE, 2013). Students aged 14-16 years who sit a General Certificate of Secondary Education (GCSE) Literature examinations should read and appreciate English literary heritage texts including poetry from 1789 to the present day (DfE, 2013). Students' written poetry, together with speaking and listening poetry activities, are not formally assessed. Making comparisons between previously unseen poetry texts and writing critically in an examination are two difficult analytical skills that need to be mastered at this level (Author, 2012; Xerri, 2013). Learning about poetry could be more readily supported if greater emphasis was placed on using students' unassessed poetry writing to consolidate their engagement with unseen texts (Lockney \& Proudfoot, 2013).

Students' and teachers' attitudes to poetry vary considerably in different contexts and age phases. Poetry can be treated with suspicion as 'other' and irrelevant to young people's lives (Benton, 1984), a puzzle to be solved (Author, 2002) or a text to be beaten for meaning (Snapper, 2012). In contrast, Ofsted notes how poetry can make young people think differently about experiences and the world around them (2007). In some secondary classrooms, poetry is undoubtedly alive, aloud and thriving (Bluett, 2015; Parton, 2015) but, elsewhere, students' poetic encounters are limited to poetry as a 'packaged commodity' (Hennessy \& McNamara, 2011, p. 217) solely for assessment purposes. This ambivalence to poetry contrasts with the interest in poetry shown in some sections of society where the genre continues to find new audiences through festivals, slam or Spoken Word events and openmic readings.

\section{Spoken Word Discourse}

Spoken Word embraces varied poetic and prose forms 'including rap and other highly vernacular verbal forms' (Damon, 1998, p. 332). It draws on poetic conventions found in oral traditions including rhythm, rhyme and repetition. It embraces popular culture, personal and political events. The term 'Spoken Word movement' characterises the genre's political nature. Spoken word artists, who often also call themselves poets, come from many walks of life and seldom conform to the traditional image of the solitary poet in their lonely garret. They might run workshops and compete in slam events. They may be politically active, involved in human rights or environmental campaigns. Beliefs about development 
of self knowledge, transformative practice and community empowerment underpin many artists' working practices. Weinstein and West argue that their approaches are about 'generating a social world in which art is an integral part of everyday life, in which speaking the truth means being honest about one's experiences and in which being honest in that way is a responsibility to self and community' (2012, p. 292).

Performance is an essential element of Spoken Word and a very different experience - both for performers and audiences - from readings of 'page poetry' . Texts, composed on a mobile phone, in a notebook or entirely in the artist's head, are incomplete 'until re-infused with the rhythms and melodies of the human voice' (Dyson, 2005, p. 159). They only come fully alive when performed. Bernstein describes a poetry reading as 'a public tuning' $(1998$, p. 17). Spoken Word artists might read new work or work in progress to see how others respond to it. They often perform lengthy works solely from memory. After a performance, poems might be substantially reworked or even abandoned (Andrews \& Smith, 2011).

Spoken Word events are highly interactive affairs, often with a substantial number of performers and additional 'open mic' opportunities for other local writers. A performer will know immediately how their work has been received (Taylor, 2015). Audiences are encouraged to respond enthusiastically after each performed piece, rather than wait and applaud politely at the end of a set as they might at a traditional poetry reading. Events such as slam competitions have rules about how such a spectacle (the first of which took place in a boxing ring [Clare, 2010]) should be performed. Some performers might experiment with voiced accompaniments like beat boxing ${ }^{2}$ but spoken words prevail. Repetitions, echoes, refrains and wordplay combine to convey powerful messages and to stir up audiences. The suggestion that 'spoken word' might convey a less scary, more accessible brand than that connoted by 'poetry' (Damon, 1998) could indicate why young people might be attracted to this secondary Discourse.

\section{The Spoken Word Education Programme}


Anne Haas Dyson describes how the spoken word 'quite literally can contain within it experienced worlds awaiting articulation' (2005, p. 152). The idea that Spoken Word practices can initiate and support revelation of unspoken feelings is a central premise in Spoken Word education and a key motivation for the SWEP's founder, Chicago-based high school teacher and poet, Peter Kahn. Kahn states that 'students need to know their stories, their voices matter to adults and to each other. It is most imperative in times like these' (Sutton, 2014). Development of critical literacy skills and an ability to articulate experiences have long been recognised as vital to full and critical participation in society (Freire, 1972). Subsequently, writers demonstrate a need for young people to use critical frameworks in their reading and construction of everyday or literary/aesthetic texts (Mission \& Morgan 2006; Janks, 2010).

The SWEP originated by Kahn began as a pilot during 2012 -13. It ran alongside a newly validated Writer/Teacher MA course and encompassed a nine month (one-day-a-week) placement for six Spoken Word artists. They worked with Kahn in a UK state secondary school as trainee Spoken Word Educators (SWEs). All six were veteran performers at Spoken Word events and slam competitions but with more limited school-based experience. In its second year, five of the original trainees dispersed to other schools in neighbouring London boroughs and one remained in the training school. They each worked for four days a week in their new roles with an additional day allocated for Masters study. A second cohort of trainees was placed at a base school and given opportunities to work in other schools in the programme. This pattern continued in year three with some variations. Every year the nature of schools' involvement in the programme changed in response to new funding arrangements. Established SWEs adopted different roles and new schools joined the programme.

\section{School contexts}

The SWEP schools in 2012-15 were located in boroughs with significantly high levels of child poverty. Many students were entitled to free school meals and pupil premium funding. In at least two schools, a tranche of this funding was budgeted as matched funding for Spoken Word Education 'to support the impact of literacy across the curriculum and improve rates of progress in English' (School website, 2015). The schools had high proportions of English as an additional language (EAL) students i.e. half of 
the cohort or significantly higher. Several had higher than national averages of student movement in and out of school and students who were statemented or given additional support.

\section{C) Methodology}

Qualitative data was collected during three separate external evaluations carried out during 20122015. These were commissioned by the SWEP and are reported with permission. Data collection was challenging. Delays in funding meant that evaluation arrangements could not be made until several months after programme commencement each year. Completion of pre-intervention interviews was therefore not possible. SWEs' timetables were subject to sudden alterations due to internal school staffing issues or changing priorities. Opportunities to visit schools often proved difficult to negotiate individually with different school gatekeepers. Given the pressure and intensity of school environments, these problems were not completely surprising nor were they insurmountable. However, they resulted in intense data collection periods.

The material was collected ethically with informed consent of participants. School names were anonymised to preserve confidentiality. Data was collected through: audio recorded semi-structured interviews; observations; detailed examination of documents and video recordings. The sample interview participants were: nine groups (of varying sizes and ages) of students aged 11 - 18 from four schools (total number 120); fifteen spoken word artists and poets (including trainee and experienced SWEs and those supporting the training); twelve secondary English and Humanities teachers, some of whom were interviewed twice during different years of the programme; three school support staff (one librarians and two learning support teachers).

Data collection took place during February - July each year. Data was analysed interpretatively, using open and then axial coding, initially with reference to five key areas required by the SWEP's funders: implementation; support; impact; legacy and sustainability. For example, through coding for references to 'implementation' specific codes emerged related to behaviour management systems, school policies, timetabling and staffing hierachies, all of which had a direct bearing on how, at a macro 
level, the SWEP was implemented within schools' established routines. These codes developed into the theme of school learning environments.

When coding data about SWEP enactment at a micro (classroom) level (through SWEs' planning, resourcing, the principles underpinning teaching and learning strategies and the outcomes achieved) the nature of SWEP pedagogy emerged as a second key theme. Three other significant themes pertaining to students' listening, student and teacher confidence and students' socialisation (including peer support and mutual respect) within their classroom learning and extra-curricular poetry events emerged from coding data specifically about 'impact' and from additional sources. These included data primarily focused on implementation, legacy and sustainability. Analysis of five themes has contributed to this paper's focus: how has an introduction to the secondary Discourse of Spoken Word made poetry a memorable learning experience for young people?

I will now explain how the SWEP was timetabled and the SWEs' roles before continuing to consider the programme's distinctive impacts on students' learning.

\section{Timetables}

Timetabling arrangements were interpreted differently by each school. From the onset trainee SWEs taught for one day a week and were involved in weekly after school SWCs for half a day. In the second and third years of the programme, experienced SWEs were contracted to take assigned KS3 English classes for $10-12$ sessions per class and lead an after-school spoken word club during four days each week. Some also led occasional short poetry club slots at lunchtimes. Some SWEs taught additional subject sessions including Business Studies, Music and Citizenship or worked with SEN and EAL classes. Schedules were subject to sudden changes caused by staff absences, lack of classroom space or shifting school priorities such as assessment preparation. Although GCSE classes were 'off limits' in some schools due to other curriculum priorities, elsewhere (notably at Brooks, Clare, Eliot and Holub) English teachers recognised what spoken word poets could offer to GCSE and Advanced level poetry study and asked poets to lead sessions with examination classes. 


\section{SWEs' roles within school learning environments}

SWEs held unique positions in their schools. They were not qualified English teachers or support staff. Their employment arrangements were very temporary. Their identity, purpose and place within school hierarchies were often not fully apparent to new colleagues. At best they were only partial members of school communities. Nevertheless, they were expected to support and adhere to policies/Discourses regarding behaviour and learning. When interviewed, SWEs frequently described themselves as 'embedded' within their schools for a creative purpose. This suggests that like war artists, embedded within military units, they became familiar with the rules of engagement and had to abide by them without the authority to implement change.

During observations, I witnessed instances where expectations about behaviour were tested. These included: fights in public spaces; students reprimanded for looking down when walking up a flight of stairs, arriving late or carrying non-regulation school bags; students placed in after-school detention and unable to attend spoken word club; a whole school senior staff 'sweep' for a missing mobile phone; a student removed from a Spoken Word Club (SWC) to attend a literacy intervention class. SWEs were present when each incident occurred. They seemed embarrassed by their personal powerlessness to intervene. None of these incidents, per se, will surprise anyone familiar with contemporary UK secondary schools. Unsurprisingly, students involved were some of those students at the edges who were beginning to benefit from working with spoken word artists. For me, the two latter incidents illustrated what could happen when the secondary Discourse of school learning confronts or overrides spoken word Discourse. During the 'sweep' Yr 7 students who listened attentively to a poem showed palpable fear and anger as they waited for a senior teacher to inspect their belongings. Once over, some students were eager to talk about what had happened. Both SWE and regular class teacher salvaged the remainder of the lesson by defusing students' indignation and refocusing attention on the poem. The second incident (removal from a SWC) underlined the different learning priorities of student, parent and the teacher of a core (compulsory) subject. It would seem that the student's after school time was not their own. A teacher ordered the student to go directly to the literacy intervention group. She contacted a parent by phone to gain support for this action. A protracted discussion ensued during which the SWE endeavoured to understand the situation and 
initiate reading/drafting of food poems by the remaining students. Intervention classes are very common in English schools. They provide additional support in core subjects for those who are considered in danger of not meeting target grades. The boundaries of this particular student's 'socialisation' (Biesta 2010: 19) within the school's learning Discourse were clearly demarcated and could not be contested by the SWE. The voluntary SWC could not be participated in until the student had improved their literacy skills through the formal intervention pathways for learning which had priority.

\section{Impact on poetry learning}

The SWEP's distinctive poetry pedagogy and its impact on students' learning will now be explored. Students (and teachers) who worked with 'embedded' poets discovered that they had very particular approaches in terms of:

a) Choice of subjects for writing

b) Poem selection

c) Talk about poetry texts and writers

d) Writing processes

e) Listening

f) Collaboration and performance

The class teacher and regular learning support staff were in the room during timetabled spoken word sessions (and at some after school SWCS ). The intention was to facilitate a shared learning experience in which teachers would participate, learn themselves from a practising spoken word artist and support SWEs in their engagement with young people. Teacher involvement was variable in observed lessons. In some sessions, English and Humanities teachers wrote alongside classes, team-taught with the poet or supported certain students. In others, teachers sat at the side either quietly observing, marking or monitoring individual students' behaviour.

\section{a) Choice of subjects for writing}

The students soon discovered that the poets had lives beyond the classroom. They were spoken word performers, slam competitors, who tried out new material on audiences at night and redrafted it in the 
light of feedback. SWEs expressed opinions about language, politics, authority, love, death, pain, London life, the environment and much more through their artistic work. Exploration of personal/emotional events with students took its toll. Many SWEs emphasised that they also needed support to ensure creative and self preservation while they were simultaneously supporting young people's emotional literacy development.

SWEs were made fully aware of child protection and safeguarding issues and subjected to enhanced disclosure checks prior to project commencement. It is evident that they took these responsibilities seriously. In the SWEP's first three years each new cohort had to confront tensions between themselves as poets who were used to performing on a spoken word stage where exploration of controversial issues was seen as almost de rigeur and school senior managers who had to consider what was deemed as 'appropriate' within a school's own context, spiritual and cultural parameters. Students wrote about personal - in some cases disturbing - topics including events in their school communities. It is inappropriate to go into specific detail here as this could compromise confidentiality. Nevertheless, it was significant that the extent of each school's intervention into publication or public performance of works on certain topics was markedly varied. One SWE commented: 'we don't want them to write happy clappy poems, we want them to be creative and self expressive'. A second observed: 'if you are telling people that they can express how they feel and to own it... it can be frightening for an adult who is not used to that.' The poets recognised that they were working with hormonal teenagers, some recently arrived in the UK, living in relatively deprived localities. Although they were not teachers with 'in loco parentis' roles, they acknowledged their duty of care for students.

The range of topics in students' poems was considerable. It encompassed many examples of 11 - 18 year olds coming to terms with aspects of emotional literacy through writing. They wrote about: identity, origins and journeys; arguments with friends and family; suffering and loss of loved ones; dislocation and learning as the poem extracts in Figure 1 show: As they grew more confident with Spoken Word, students showed a desire to explore current issues such as environmental, political or breaking news stories. In a Yr 8 group interview, one Clare student 
said she was ready, after six months' participation, to write about more than just where 'I come from' (a common starting point in many of the schools). She wanted to write about 'other people, global issues and stuff.' Other students echoed this view. They seemed to indicate a high level of confidence, not only in newly-honed writing skills but also in an understanding of reasons for writing texts that went beyond the personal. Some SWEs were able to respond to this development more readily than others. They supported students' writing about topics including young women's rights to education, food waste, Islamophobia and the 2015 UK General Election. These activities led to publications, public performances, competition entries and, in one case, a prize winning video. Figure 2 includes three extracts on different topics:

Comment [SD2]: Figure 2 here

Significantly, young people also wrote about discovering the importance of writing, Spoken Word and poetry in their lives as examples in Figure 3 illustrate:

The above pieces convey how students' learning about writing empowered and enriched their lives. It enabled them to escape from previous experiences or redefine how they wanted others to perceive them. The line 'I am made of words beyond silence', written and performed in a long poem by a Yr 12 female student, exemplifies Dyson's view that Spoken Word contains within it 'experienced worlds awaiting articulation' $(2005$, p. 152). Its writer sees language as a vital element of what makes her who she is. Within the measured simplicity of her language resides a strong statement of intent: these words have given her a voice, one with which she can overcome silence and tell her stories to anyone who will listen. Stein contends that poetry has been 'neutered' (2010, p. 189) in the classroom. But the SWEP has enabled young people to understand that there are many potential subjects for writing and poetry can be a vehicle through which these can be explored in provocative and challenging ways.

\section{b) Selection of poems and writers}

Choice of subject is just one aspect of Spoken Word Discourse that students were introduced to. Students were given the chance to read and discuss poems by a wide variety of writers. Poems used were often written by living, local writers that the SWEs admired. These included poets appearing on the Spoken Word circuit (some of whom visited the schools or performed alongside SWEP writers) and 
those who wrote page poetry. Other poems used were new discoveries from Masters workshops. Texts were sometimes grouped thematically and presented through a variety of media such as YouTube or audio clips, PowerPoint or Prezzi slides or photocopies. The SWEs usually included a printed or performed version of a poem of their own in each session.

For many $\mathrm{Yr} 7$ - 13 students, pre-selected examination poetry (from current and legacy anthologies) has become their sole experience of poetry (Author 2012a). However, none of the texts used in observed sessions were taken from examination anthologies or unseen examination papers. This does not mean the SWEs avoided GCSE poems, rather that examination poems were additional to their varied selections. Overall, a strikingly fresh range of poets was used. This encompassed a substantial number of contemporary European and American writers alongside 20th and some pre-20th century poets including:

Chris Abani, Christin O'Keefe Aptowich, Billy Collins, Kai Davis, Stephen Dobyns, Thomas Sayers Ellis, Andrea Gibson, Nikki Giovanni, Nazim Hikmet, Ted Hughes, Jackie Kay, Kenneth Koch, Kei Miller, Shamira Nelson, Aimee Nezhukumatathil, Roger Robinson, William Shakespeare, Warsan Shire, Sojourner Truth plus work by the Spoken Word artists themselves and poems by their students.

What could this selection have indicated to students? It signalled that both new page and Spoken Word poetry was published and performed regularly, was worthy of discussion and as a stimulus for learning. It reinforced that poets could be people known to the students, from diverse backgrounds, living in communities like their own. One year 8 student said she realised 'Poetry is not a special club' but that it was open to all because poems could be written by ordinary people and be about ordinary events in their lives. For her, and some of her peers, poetry had been removed from the 'pedestal' (Author, 2001, p. 39) on which it had all too often been placed. This discovery marked a significant stage in the students' literacy development and their enculturation into the secondary Discourse of Spoken Word. 


\section{c) Talk about poems}

The way students were encouraged by the SWEs to talk about poems differed from approaches that have been adopted in many English classrooms. In the last thirty years a distinct body of poetry has been overused and tainted by 'the dead hand of the exam' (Author, 2002, p. 87). A further tranche has become unseen, unfamiliar poetry to be feared rather than new work to be enjoyed (Author, 2012). Poems have become products to be pinned down, compared with others and analysed, with reference to a number of acronyms, in preparation for a written test.

Unlike their teacher colleagues, the poets were not teaching under the exam cosh. Six SWEs, with differing levels of experience, showed considerable common ground in how they introduced poems. Skilful use of what Douglas Barnes or Neil Mercer might describe as 'exploratory talk' (Barnes, 2008, p. 5) was a key feature of the learning. SWEs opened up class discussion after several readings/hearings of a poem by encouraging students to share tentative, not fully formed personal responses as they tried out initial ideas. Students were asked to identify their own 'striking lines' from the writing, explore why these lines had struck them and their views on how language worked in each chosen line. These approaches seemed more light touch than that of a conventional poetry lesson: the SWEs were comfortable that poems might not be completely understood and thus braver (than some teachers might have been) in leaving certain lines unspoken about. They emphasised developing students' understanding of creative ways that poetic language could be used to capture experiences and ideas. In many cases the poetry was linguistically challenging but students seemed prepared to suspend their disbelief and be taken on a journey of imagination through language. During discussion, SWEs wove in occasional references to other poems by the same writer or poets who adopted similar techniques. (For example discussion of Nikki Giovanni's use of metaphor included references to other Giovanni poems along with those by Shakespeare and others). In this way, SWEs developed students' understanding that poets produce a body of work beyond a single poem being discussed and that poets are influenced by other writers. Ultimately, these class discussions lead on to use of the poems as starting points for writing. However, students were not expected to slavishly adopt a poem's structure or language as a model. They could choose to take as little or as much as they liked from each text to inform their work. 


\section{d) Writing processes}

Barrs urges that poetry writing should be a 'habit of mind' (2015, p. 103). For these students, writing was modelled by SWEs as an act of creative composition that could occur on A4 paper, mobile phone, computer or in a notebook. It could happen anywhere - on the tube, in a cafe, on the kitchen table and over any period of time. Students were also encouraged to draft and keep copies of work in progress in notebooks separate from their subject work. One SWE also experimented successfully with using voice recorders in poetry writing.

During the writing stages, students were required to concentrate on drafting ideas and respect that others needed periods of silence too. One SWE asked Yr 10 students for 'Zen temple silence'. The group clearly understood and responded accordingly. SWEs and, in some cases, teachers, circulated and supported individuals. In observed KS3 and KS4 lessons SWEs talked quietly to students, tried to shape students' words into potential starting lines or helped them with prompt phrases. At key points students were encouraged to share work in progress and comment - usually orally - on each other's work. At Brooks, some students drafted new work very quickly and several of them stayed to talk to about this with the SWE when a lesson was over. The majority of students responded well to their SWE: they were fully engaged in their poetry activities and keen to show their appreciation of the poet.

The atmosphere in SWCS was more relaxed than in scheduled lessons and potentially more conducive for students who wanted freedom to write at their own pace. In two schools students brought work-inprogress with them. Within an hour one Clare student wrote three new poems and read them aloud. During this session the SWE worked hard to keep students focused, giving them plenty of choices and starting points for writing, offering some critique and encouraging students to join in. Emphasis was placed on developing precise word choices and learning to play with words in distinctive ways. Rapport between SWE and students was demonstrable. Yet again several students were reluctant to leave. Elsewhere, one Yr 12 Auden student performed, entirely from memory, a lengthy new draft that others in the group had heard previously in a different version. The group listened intently and commented on what they liked about the revised piece. A Yr 10 student then spoke very precisely about the 
changes in the draft he had just heard. No one had a hard copy of the redraft to refer to but the students were fully engaged and supportive. This was an astonishing event to experience. Above all else observed, it encapsulated the distinctive nature of this secondary Discourse and the impact that such shared social practice can have on learning about poetry.

\section{e) Listening}

It has been argued that Spoken Word fosters a 'culture of listening' and valuing words (Fisher, 2005, p. 128). Both elements were frequently observed in sessions. Listening is extremely difficult to teach but an essential skill to learn. The need for careful and respectful listening was stressed by the SWEs and students' listening behaviours were impressive in many sessions. They listened attentively to peers' ideas and draft work. In first term evaluations $\operatorname{Yr} 7$ and $\mathrm{Yr} 9$ Fanthorpe students identified 'listening to other people's poetry' as the most enjoyable aspect of the programme. Their ability to recall what they had heard in a previous session (or draft) was, in some cases, extraordinary. In Year group events and community performances students in pairs and groups performed complex poems from memory. Turntaking and choral sections were common features. Such performances required considerable concentration and attention to timing. The students (and their teachers) also acquired an understanding of how spoken word audiences behaved. In contrast to page poetry performances, which are frequently conducted in silence until a poet finishes their set, this audience is typically very reactive. The students clicked fingers enthusiastically, clapped rapturously and shouted encouraging whoops in response to striking lines as soon as they were performed.

\section{f) Collaboration and performance}

Bruner states that children learn through discovery and invention. Creative inquiry processes are coupled with those of negotiation and sharing ideas with others (1986). Collaboration, in exploring and creating meaning, is central to Spoken Word practices. Poets provided many examples of the transformative nature of the work. They stated that students gained a heightened appreciation of their peers' lives and, through this, a stronger sense of community. Examples included: a student who told her class about her mother's cancer; another student who offered comfort when a girl cried and a third student who spoke about 'the privilege of having a family to go home to and every kid in the classroom 
welled up'. One poet described how a Yr 8 group were able to explain to a large public audience 'why poetry was as much about community as craft'. She felt this was a 'seminal' moment in their learning about the genre's potential power. The students drew on these understandings in their collaborative creative work. A sense of shared endeavour permeated their SWCS, rehearsals and performances. Written pieces were individually crafted but many became reworked and mashed up with others for performance. Criticality and teamwork were highly evident. Brooks' SWC students watched the film of a public performance that many had taken part in the previous week. They fed back on their achievements, praised each other and talked about how they would improve what were already highly polished and professional performances. When rehearsing for a public performance, Auden students worked on the speed and pace of their delivery, strategies for improvisation, maintaining audience attention and focusing on key issues in a poem. Their warm-up circle activities reinforced their 'family' of performers (from years 7 - 12) and their determination to 'show everyone what we have got to say'. The showcases were vibrant, joyful, touching and inspiring events. They demonstrated Spoken Word's power to galvanise young people to find their voices and provoke audience responses in ways that were far removed from formal assessments of their writing. At Auden and other schools, SWEs introduced 'team captain' or 'head poet' designations. These roles appeared to engender individuals with a considerable sense of responsibility for their fellow performers. Arguably this enhanced status placed them on an equal footing with senior students involved in extra-curricular sporting activities where success, in terms of results, was much more easily recognised within school learning Discourse.

\section{Conclusions}

\section{Self perception}

Through their reading, listening, talk, writing and performances many students seemed to develop greater confidence and self belief. Those who were previously shy or reluctant to join in begun to answer questions or read in class, share their ideas with their peers and perform for the first time on very public stages. 'Confidence' and expressing myself' frequently occured in students' descriptions of their new skills. A SWE spoke of Clare students who had changed from being 'the ones you never see' and surprised their teachers by how forthcoming they were. A poet attached to Fanthorpe School described a student who had 'found a way to be herself' and to talk openly about how she had been mistreated by others. Another commented on how the 'inherent talent' in a Year 7 Auden class was 
nowhere near as impressive as the 'non-vocal' students who became 'vocal' after six lessons of input. One teacher remarked on a Year 8 student's increased 'confidence in their ability to produce creative work' while another stated 'students who have felt voiceless have been given a platform.' Engagement with Spoken Word Discourse had, therefore, not only changed students' views of poetry but also their self perception.

\section{How has poetry become a memorable learning experience?}

The SWEP offered students new conditions and dispositions for learning (Anderson 2015: 35) which contributed to their cultural enrichment. Through their involvement, young people began to use poetry as a vehicle for their self expression, secure in the knowledge that they might have something of value to say that others wanted to hear, especially if they could use language in exciting ways. In doing so, the genre became important to them personally. Spoken Word poetry lessons and workshops were perceived as being 'more personal to us than English' by $\mathrm{Yr} 8$ students. Poetry also provided a vital stimulus that enabled these young, sometimes vulnerable, people to interact more openly with their peers. One student felt she had been given the chance to talk about 'what people are thinking and feeling'. Another said that poetry 'allows you to let the feelings out'. A third, confessing they were 'not really a poetry person', described how the SWE had 'inspired' them to engage with poetry. Through immersion in poetry, some had developed greater confidence in their ability to write poems independently. A Yr 9 Fanthorpe student relished 'the ability to write poems freely'. A Yr 8 Clare student commented perceptively on her progress with poetry writing: 'it's not really hard once you know what you are doing. Not filling in the blanks is better. Filling in the blanks feels too restrictive.' This student was ready to break free from the overly structured approach (of using writing frameworks or restrictive models) which characterises many school poetry lessons (Author, 2003). She was ready to make more decisions about vocabulary and form for herself.

According to their teachers, many SWEP participants were also more confident in applying their understanding to analysis of particular examination poems and other texts. A Brooks teacher noted the improvement in students' ability to critique other people's work and the increased use of figurative language in their writing. Teachers from three schools said their students were being stretched 
creatively. One said it was 'fantastic' to see how students' new poetic insights were permeating their discussions in English lessons. Two teachers noted that their school's KS3 students were now 'well prepared' for GCSE level analysis of poetry and other texts. Occasionally student evaluations also commented on poetry and examinations. For example, one wrote: 'it would help me if I had a poetry essay I would remember stuff about the workshop' while a second had learned 'new words which I can use in my test paper (and get more marks for it.)'

However, engagement with the genre extended beyond GCSE preparation. For these students, poetry was no longer tied solely to writing 'schooled responses' (Misson and Morgan 2006, p. 107). Poetry had taken off its school uniform. Through their introduction to the secondary Discourse of Spoken Word, the act of creating, sharing and critiquing texts had become a more integral, accepted, even ordinary part of these young people's lives. The students' insights into the social practices of Spoken Word opened the door to a new, and potentially transformational, writing community where, one $\operatorname{Yr} 8$ girl told me, 'we can find the freedom to break out of our cages'.

\section{References}

Anderson, G. (2015). 'What is knowledge in English and where does it come from?' Changing English:

Studies in Culture and Education, 22, 1, 26- 37.

Andrews, R. \& Smith, A. (2011). Developing Writers: Teaching and Learning in the Digital Age.

Berkshire, Open University Press/McGraw-Hill.

Author. (2001). Taking Poetry off its pedestal: the place of poetry writing in an assessment driven curriculum. English in Education, 35, 3, 32 - 41.

Author. (2002). The Dead Hand of the Exam: the impact of the NEAB anthology on poetry teaching at GCSE. Changing English, 9, 1, 85-92.

Author. (2003) Drafting and Assessing Poetry. London, Paul Chapman Publishing. 
Author. (2012). Poetry is an unfamiliar text: locating poetry in Secondary English classrooms in New Zealand and England during a period of curriculum change. Changing English, 19, 4, 395-410.

Author. (2016). Integrating poetry-focused digital technology within a literacy teacher education course. In C. Kosnik, S. White, C. Beck, B. Marshall, A. Lon Goodwin \& J. Murray (Eds) Building Bridges: Rethinking Literacy Teacher Education in a Digital Era. Rotterdam, NL, Sense Publications, 59 - 76. Author. \& Hughes, J. (2009). Using a poetry wiki: how can the medium support pre-service teachers of English in their professional learning about writing poetry and teaching poetry writing in a digital age? English Teaching Practice and Critique, 8, 3, 91-106.

Ball, S. (2012). Performativity, Commodification and Commitment: An I-Spy Guide to the Neoliberal University. British Journal of Educational Studies, 60, 1, 17-28.

Barnes, D. (2008) Exploratory talk for learning. In Mercer, N. \& Hodgkinson, S. (Eds) (2008). Exploring Talk in School: Inspired by the Work of Douglas Barnes. London, Sage, 1 -15.

Barrs, M. (2015). A flicker in the mind. In Author., M. Barrs, A. Lambirth \& A. Wilson (Eds) Making

Poetry Happen: transforming the poetry classroom. London, Bloomsbury, $97-106$.

Benton, P. (1984). Teaching Poetry: the rhetoric and the reality. Oxford Review of Education, 10, 3, 319 $-327$.

Benton, P. (2000). The Conveyor Belt Curriculum? Poetry teaching in the secondary school II. Oxford Review of Education, 26, 1, 81-93.

Bernstein, C. (1998). Close Listening: Poetry and the Performed Word. New York, Oxford University Press.

Biesta, G. (2010). Good education in an age of measurement: Ethics. politics, democracy. Boulder, CO: Paradigm.

20 
Bluett, J. (2015). Making Poetry Happen in a Sixth Form Environment. In Author, M. Barrs, A. Lambirth \& A. Wilson (Eds) Making Poetry Happen: transforming the poetry classroom. London, Bloomsbury, 8795. Bruner, J. (1986). Actual Minds, Possible Worlds. Cambridge, MA: Harvard University Press.

Clare, T. (2010). Slam: A Poetic Dialogue. In T. Chivers (Ed) Stress Fractures: Essays on poetry. London, Penned in the Margins, 135 - 140.

Clark, C. (1998). Discipline in schools, British Journal of Educational Studies, 46, 3, 289-301.

Damon, M. (1998). Was That "Different" "Dissident" or "Dissonant"? Poetry (n) the Public Spear: Slams, Open Readings, and Dissident Traditions. In C. Bernstein (Ed) Close Listening: Poetry and the Performed Word. New York, Oxford University Press, 324-342.

Department for Education (2013). National Curriculum.

https://www.gov.uk/government/publications/national-curriculum-in-england-framework-for-keystages-1-to-4 Accessed 20/7/16.

Department for Education (2015). Behaviour and discipline in schools. Advice for headteachers and school staff. January 2016. DFE-00023-2014 Accessed 15/2/16.

https://www.gov.uk/government/publications/behaviour-and-discipline-in-schools

Dyson, A. H. (2005). Crafting "The humble prose of living": Rethinking oral/written relations in the echoes of spoken word. English Education, 37, 2, 149-164.

Fisher, M. T. (2005). From the Coffee House to the School House: The Promise and Potential of Spoken Word Poetry in School Contexts. English Education, 37, 2, 115-131.

Freire, P. (1972). Pedagogy of the Oppressed. Harmondsworth, Penguin.

Gee, J. (2015). Social Linguistics and Literacies: ideology in discourses. London, Routledge. (5th Edn) 
Hennessy, J. \& McNamara, P. (2011). Packaging Poetry. Pupils' perspectives of their learning experience within the post-primary poetry classroom. English in Education, 45, 3, 206-23. Hirsch, E. (2012). Hirsch and Cultural Literacy. http://www.coreknowledge.org.uk/culturalliteracyck.php Accessed 15/2/16. Janks, H. (2010). Literacy and Power. London, Routledge.

Locke, T. (2009). The disappearance of enjoyment: How literature went wandering in the literacy woods and got lost. In J. Manuel, P., Brock, D., Carter \& W. Sawyer (Eds) Imagination, innovation, creativity: Re-visioning English in education. Putney, NSW, Phoenix Education, 123-138.

Lockney, K. \& Proudfoot, K. (2013). Writing the Unseen Poem: can the writing of poetry help to support pupils' engagement in the reading of poetry? English in Education, 47, 2, 147 - 162.

Maguire, M., Ball, S. \& Braun, A. (2010). Behaviour, classroom management and student 'control': enacting policy in the English secondary school. International Studies in Sociology of Education, 20, 2, 153-170.

Misson, R. \& Morgan, W. (2006). Critical Literacy and the Aesthetic: transforming the English classroom. Urbana, IL, National College of Teachers of English.

Ofsted (2007). The Teaching of Poetry in Schools. London, HMSO.

Ofsted (2015). The common inspection framework: education, skills and early years. London, HMSO. Accessed 15/2/16 https://www.gov.uk/government/publications/common-inspection-frameworkeducation-skills-and early-years-from-september-2015.

Parton, C. (2015). Case Study VI: How English teachers use slam poetry in a secondary school setting. In Author, M. Barrs, A. Lambirth \& A. Wilson (Eds) Making Poetry Happen: transforming the poetry classroom. London, Bloomsbury, 133 - 140.

22 
Perryman, J., Ball, S., Maguire, M. \& Braun, A. (2011). Life in the Pressure Cooker - School League Tables and English and Mathematics Teachers' Responses to Accountability in a Results-Driven Era. British Journal of Educational Studies, 59, 2, 179-195.

Pring, R. (2012) Putting persons back into education. Oxford Review of Education, 38, 6, 747-760.

Sadler, D. R. (1989). Formative assessment and the design of instructional systems. Instructional Science, 18, 2, 119-144.

Scribner, S. \& Cole, M. (1981). The Psychology of Literacy. Cambridge, MA, Harvard University Press. Snapper, G. (2012). Exploring resistance to poetry in Advanced English studies. In Author, A. Lambirth \& A. Wilson (Eds) Making Poetry Matter: international research on poetry pedagogy London, Bloomsbury, $31-41$.

Stein, K. (2010). Poetry's afterlife. Verse in the digital age. Ann Arbor, University of Michigan Press.

Sutton, S. L. (2014). Poetry in Perilous Times: Peter Kahn \& The Gravity of Young Voices. Chicago Literati, 5/6/14 http://chicagoliterati.com/2014/06/05/poetry-in-perilous-times-peter-kahn-thegravity-of-young-voices/ Accessed 17/2/16

Taylor, J. (2015). Slam Poetry. In Author, M. Barrs, A. Lambirth \& A. Wilson (Eds) Making Poetry Happen: transforming the poetry classroom. London, Bloomsbury, 125 -132.

Weinstein, S. \& West, A. (2012). Call and responsibility: critical questions for youth spoken word poetry. Harvard Educational Review, 82, 2, 282 - 302.

Wenger, E. (1997). Communities of practice: Learning, meaning and identity. Cambridge, Cambridge University Press. 
Xerri, D. (2013). 'Colluding in the 'Torture' of poetry: shared beliefs and assessment'. English in Education, 47, 2, 134- 146.

Yandell. J. (2011). Agency and the canon: Your Shakespeare, everybody's Shakespeare? In B. Doecke, L. McLean Davies \& P. Mead (Eds) Teaching Australian Literature. Kent Town, South Australia, Wakefield Press, $213-230$.

\footnotetext{
${ }^{1}$ Pupil Premium is 'additional funding for publicly funded schools in England to raise the attainment of disadvantaged pupils and close the gap between them and their peers' (www.gov.uk: accessed 26/7/16).

${ }^{2}$ Beat boxing is a percussive sound created by mouth to emulate a drum and bass line track.
} 


\section{Figure 1}

I'm from concrete streets where children play tag sell flower necklaces outside churches, just so they can feed their younger siblings ( $\mathrm{r} 9$ student)

My city weeps in shadows and longs for kites that will not fly in its sullen helicopter skies. (Yr 11 student)

Let them know what you have become How the white plasticine with hips Turned into an unique colourful figure you call yourself (Yr 11 student)

That's why I'm practising my English, so I can't be an alien (Yr 10 student)

I'm gonna learn to play the game I'm trying to bounce from the bottom to the top of the league.... Not a wasteman that lives in a wasteland. ( $\mathrm{Yr} 7$ student)

If I lost my special needs I could Say good-bye to my notebook Race through homework like Usain Bolt Skip through paragraphs and fly through books My mouth would be unzipped (Yr 10 student) 


\section{Figure 2}

\section{Bullets - Malala}

Beat down with a single bullet.

Since when did FEMALE mean no, you CAN'T DO THIS?

(Year 12 student)

Don't waste food please understand

the pain of the food you hold in your hand

The world eats only a third of what they buy

so I bet you don't know how many people die

People in countries unlike our own

would like to eat half of what we've thrown

(extract from piece by students from various year groups)

\section{Its baking}

The oven door open and in goes the world.

The heat won't stop increasing.

The land turns crisp

The sky to dust

The water evaporate[s]

And there is nothing left but us

(Yr 8 student) 


\section{Figure 3}

Next time you pick up a pen

acknowledge the power within it ( $\mathrm{Yr} 10$ student)

And that day when my black ink slowly caressed the paper I stood up

I grabbed my hope, pride and dignity

Filled my lungs with oxygen

Dusted off my cape

Emptied it of the disappointment and hate

And flew, taking the air beneath me

Which held freedom in its echoes

To a place where only my poetry defines me. (Yr 8 student)

I am made of words beyond silence. (Yr 12 student) 